\title{
Donor-Acceptor Random Copolymers Based on a Ladder-Type Nonacyclic Unit: Synthesis, Characterization, and Photovoltaic Applications
}

\author{
Chiu-Hsiang Chen, Yen-Ju Cheng, ${ }^{*}$ Chih-Yu Chang, and Chain-Shu Hsu* \\ Department of Applied Chemistry, National Chiao Tung University, 1001 Ta Hsueh Road, Hsin-Chu, 30010 Taiwan \\ Supporting Information
}

ABSTRACT: We have developed a ladder-type multifused thienyl-phenylenethienylene-phenylene-thienyl (TPTPT) unit where each thiophene ring is covalently fastened with the adjacent benzene rings by a carbon bridge, forming four cyclopentadiene rings embedded in a nonacyclic structure. This rigid and coplanar TPTPT building block was copolymerized with electron-deficient acceptors, dibromobenzothiadiazole (BT) or dibromodithienyldiketopyrrolopyrrole (DPP), via Stille polymerization. By varying the feed ratio of the monomers, a new series of random copolymers PTPTPTBT11, PTPTPTBT12, PTPTPTDPP11, PTPTPTDPP12, and PTPTPTDPP13 with tunable optical and electronic properties were prepared. The PTPTPTDPP12/PC $\mathrm{PC}_{71} \mathrm{BM}(1: 4, \mathrm{w} / \mathrm{w})$ based device exhibited the highest short circuit current $\left(J_{\text {sc }}\right)$ of $10.78 \mathrm{~mA} / \mathrm{cm}^{2}$ with a good power conversion efficiency $(\mathrm{PCE})$ of $4.3 \%$ due to the much boarder absorption ability and the highest hole mobility of PTPTPTDPP12. The devices based on PTPTPTDPP13, PTPTPTDPP11,

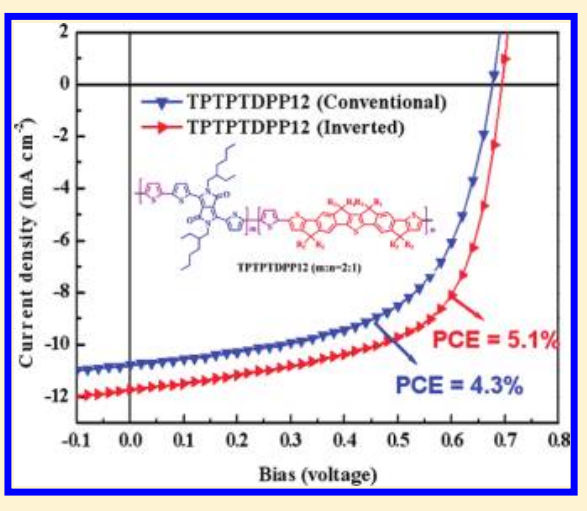
PTPTРТВT12, and PTPTPTBT11 polymers also displayed promising efficiencies of $4.1 \%, 3.6 \%, 3.1 \%$, and $2.8 \%$, respectively. Most importantly, PTPTPTDPP12 has been demonstrated as a superior low-band-gap material for polymer solar cell with inverted architecture, achieving a high PCE of 5.1\%.

\section{INTRODUCTION}

Over the past few years, tremendous research effort has been made on all-solution processed polymer solar cells (PSCs) in order to realize low-cost, light-weight, large-area, and flexible photovoltaic devices. ${ }^{1}$ To achieve high efficiency of PSCs, the most critical challenge at molecular level is to develop p-type conjugated polymers that simultaneously possess (1) sufficient solubility to guarantee solution processability and miscibility with an n-type material, (2) low band gap (LBG) for strong and broad absorption spectrum to capture more solar photons, and (3) high hole mobility for efficient charge transport. The most effective way to prepare a LBG polymer is to incorporate electron-rich donor and electron-deficient acceptor segments along the conjugated polymer backbone. ${ }^{2}$ Considerable research have been directed to the development of new electron-rich donor segments for p-type materials. ${ }^{3}$ Recent successful LBG conjugated polymers for PSCs reveal that the multifused aromatic rings with forced planarity is a common structural feature of donor segments. ${ }^{3}$ Forced planarization by covalently fastening adjacent aromatic units in the polymeric backbone provides an effective way to reduce the band gap because the parallel p-orbital interactions can facilitate $\pi$-electron delocalization and elongate effective conjugation length. ${ }^{4}$ Moreover, planar and rigid structures suppress the rotational disorder around interannular single bonds to lower the reorganization energy, which are beneficial for intrinsic charge mobility. ${ }^{5}$ The benzene-based 2,7-fluorene unit has been widely used to produce $\mathrm{D}-\mathrm{A}$ polymers that possess deep-lying HOMO energy levels to achieve higher open-circuit voltages $\left(V_{\mathrm{oc}}\right)$ for PSCs. ${ }^{6}$ However, owing to the high aromaticity of benzene ring, these polymers usually exhibit large optical band gaps that limit their light-harvesting ability and thus result in only moderate photocurrents. Structurally analogous to fluorene, tricyclic $4 H$-cyclopenta $\left[2,1-b: 3,4-b^{\prime}\right]$ dithiophene $(\mathrm{CPDT})^{7}$ is an appealing thiophene-based segment for LBG polymers. ${ }^{8}$ $\mathrm{D}-\mathrm{A}$ polymers based on CPDT unit have shown narrow optical band gaps and enhanced hole mobilities, leading to higher shortcircuit currents $\left(J_{\mathrm{sc}}\right)$. Nevertheless, the devices incorporating CPDT-based polymers usually show limited $V_{\text {oc }}$ value ca. $0.6 \mathrm{~V}$ arising from the relatively low-lying HOMO levels. Development of a new electron-rich unit that can combine the advantages of benzene-based fluorene and thiophene-based CPDT units may overcome the dilemma between $J_{\mathrm{sc}}$ and $V_{\mathrm{oc}}$. Integration of thiophene and benzene units into an entity with forced rigidification becomes a promising molecular strategy. Pentacyclic diindenothiophene (DIDT) unit is an example in this category with highly planar structure. ${ }^{9}$ Very recently, we reported a series of DIDT-based D-A copolymers and the device incorporating

Received: August 9, 2011

Revised: September 19, 2011

Published: October 11, 2011 
Scheme 1. Chemical Structure of Tricyclic Fluorene and CPDT, Pentacyclic DIDT, and Nonacyclic PTPTP Unit

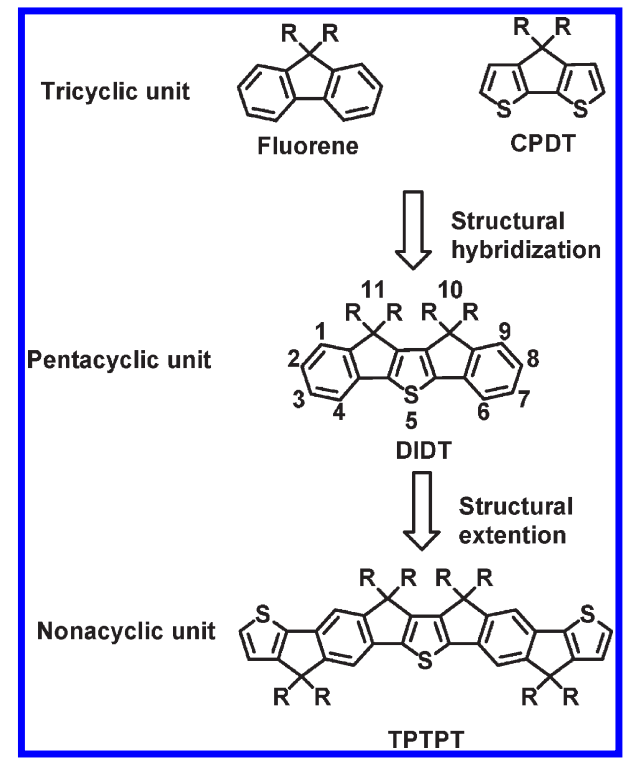

Scheme 2. Chemical Structures of Polymers PDIDTBT11, PTPTPTBT11, PTPTPTBT12, PTPTPTDPP11, PTPTPTDPP12, and PTPTPTDPP13

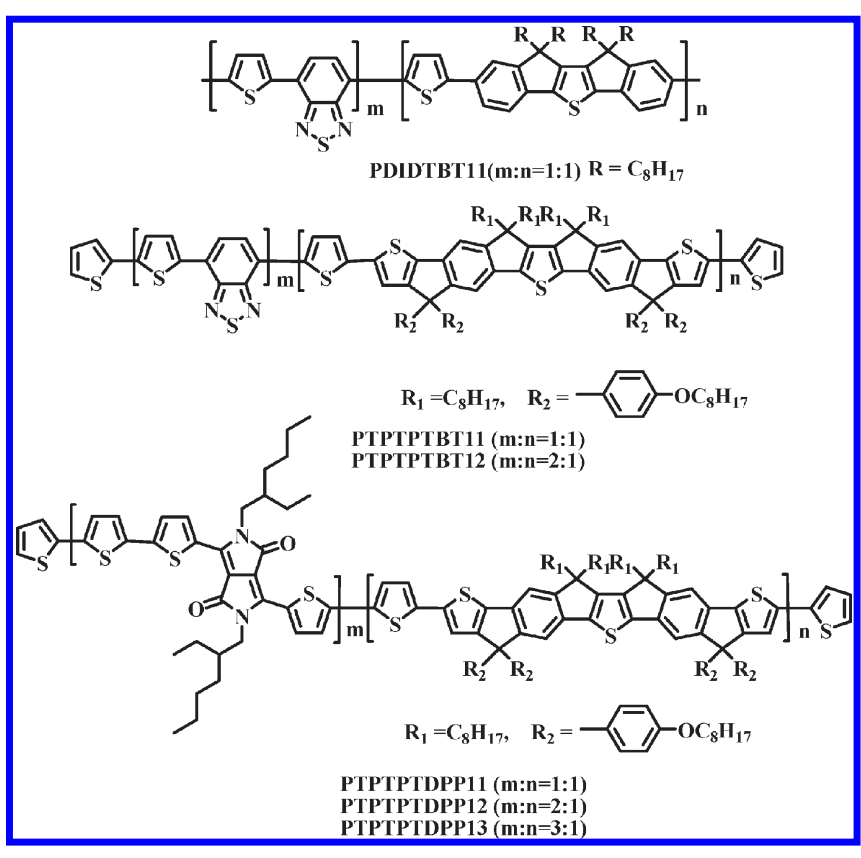

random PDIDTBT11 copolymer have exhibited a moderate PCE of $2.0 \%$ (structure shown in Scheme 2). ${ }^{10}$

If the 2,8-poistion of the DIDT unit is further elongated with two more thiophene rings through embedding two cyclopentadiene (CP) rings, a new multifused thienyl-phenylenethienylene-phenylene-thienyl (TPTPT) unit with nonacylic structure will be present (Scheme 1). Compared to the DIDT unit, TPTPT may exhibit improved optical and electronic properties due to its higher thiophene content and more extended conjugated system. The ability of functionalization at bridging carbon allows for introducing eight highly solubilizing side chains on the four CPs, making TPTPT derivatives highly soluble. On the other hand, exploration of electron-deficient units incorporated into TPTPT-based polymeric backbone is desirable. Benzothiadiazole $(\mathrm{BT})^{11}$ units are the widely used electron-deficient units due to their suitable electron affinity and easy synthesis. The diketopyrrolopyrrole (DPP) unit has also emerged as a useful acceptor unit because of its planar conjugated bicyclic structure and strong electron-withdrawing nature of polar amide group. ${ }^{12}$ Herein, we report the detailed synthesis of the dibromo-TPTPT monomer which was copolymerized with BT or DPP acceptors to prepare a new class of D-A conjugated random copolymers (Scheme 2). Their thermal, optical, and electrochemical properties have been carefully characterized. Preliminary photovoltaic performance based on these polymers show promise in both conventional and inverted solar cell devices.

\section{RESULTS AND DISCUSSION}

Synthesis. The synthesis of the monomers TPTPT is depicted in Scheme 3. Compound 5 was synthesized by following the procedure we reported earlier. ${ }^{10} 2,8$-Diboronic ester 5 was reacted with ethyl 2-bromothiophene-3-carboxylate by Suzuki coupling to obtain compound 6. Double nucleophilic addition of freshly prepared 4-(octyloxy)phenylmagnesium bromide to the ester groups of 6 led to the formation of benzylic alcohol 7, which was subjected to intramolecular annulation through acidmediated Friedel-Crafts reaction to furnish the fused nonacyclic arene TPTPT in a high yield of $81 \%$. It is noteworthy that the cyclization takes place regioselectively at the 3,7-position of the PTP unit. Bromination of TPTPT by $N$-bromosuccinimide generated Br-TPTPT in a moderate yield of $65 \%$. Random polymerization using three monomers via metal-catalyzed cross-coupling has been widely employed to tailor properties of polymers by varying the ratio of composition. ${ }^{6,13}$ With the donor monomer in hand, the copolymers PTPTPTBT11 and PTPTPTBT12 were prepared by reacting Br-TPTPT and 2,7-dibromobenzothiadiazole (BT) with 2,5-bis(trimethylstannyl)thiophene $(\mathrm{T})$ using Stille polymerization with the feed molar ratio of $\mathrm{Br}$-TPTPT to $\mathrm{BT}$ to $\mathrm{T}$ being $1: 1: 2$ and 1:2:3, respectively (Scheme 4 ). To simplify the nomenclature, we only use TPTPT and acceptor units (BT or DPP) with their molar ratios to denote the random copolymers. In a similar manner, the copolymers PTPTPTDPP11, PTPTPTDPP12, and PTPTPTDPP13 were also synthesized by using dibromodithienyldiketopyrrolopyrrole DPP as the acceptor. (Scheme 4). All the polymerization reactions were carried out under microwaveassisted condition in only $45 \mathrm{~min}$ to produce the polymers with reasonably high number-average molecular weights $\left(M_{n}\right)$ from 13 to $39 \mathrm{kDa}$. The copolymers purified by successive reprecipitation and Soxhlet extraction showed narrow molecular weight distributions with polydispersity index below 2.5 (Table 1 ). All of the intermediates, monomers, and corresponding copolymers were fully characterized by ${ }^{1} \mathrm{H} \mathrm{NMR}$ and ${ }^{13} \mathrm{C}$ NMR (see Supporting Information). The resulting copolymers showed excellent solubilities in common organic solvents, such as chloroform, toluene, chlorobenzene, and 1,2-dichlorobenzene.

Thermal Properties. Thermal properties of these polymers were analyzed by differential scanning calorimetry (DSC) and thermal gravimetric analysis (TGA) and are summarized in Table 1 . The decomposition temperatures $\left(T_{\mathrm{d}}\right)$ of the polymers 
Scheme 3. Synthesis of TPTPT Monomer

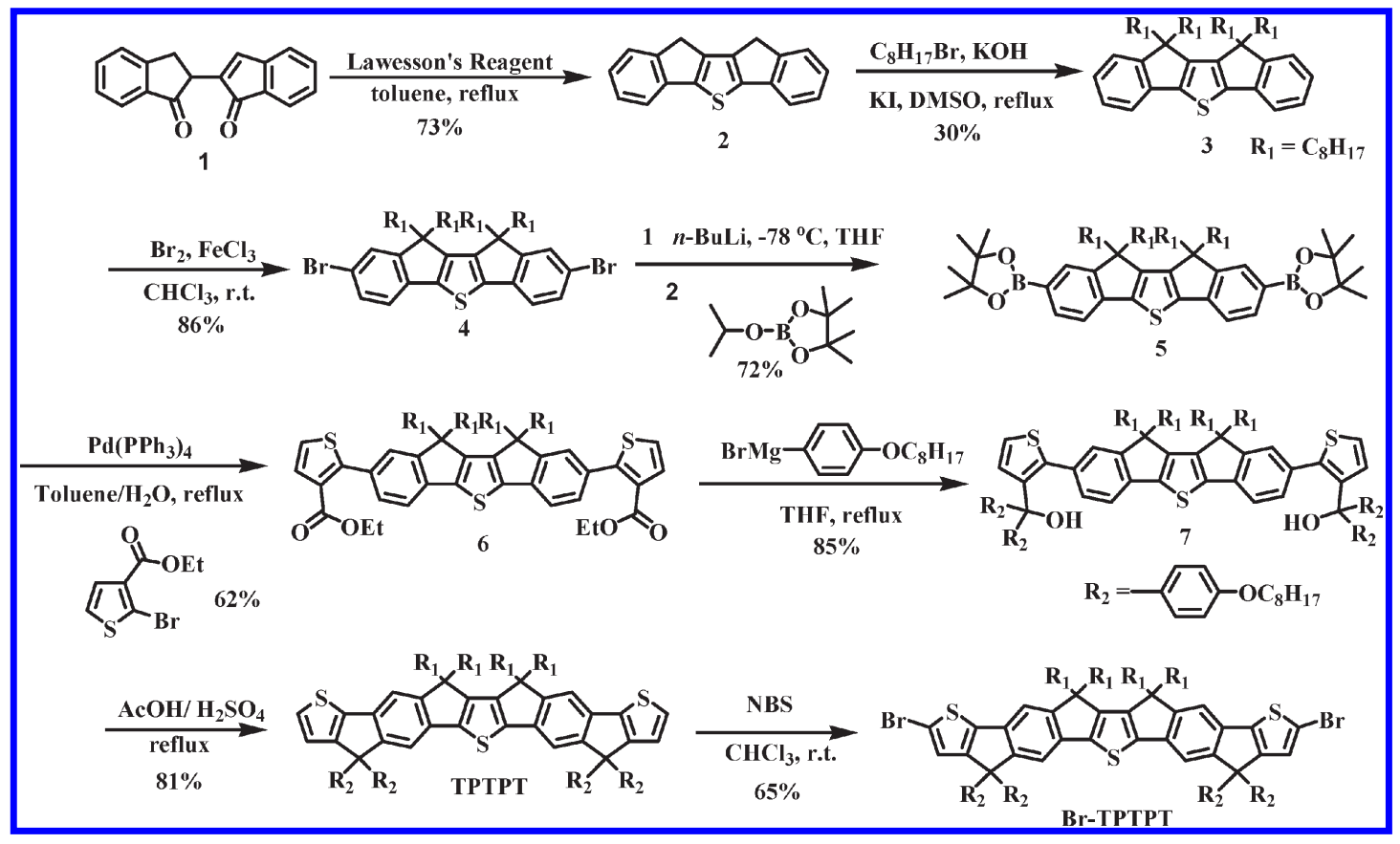

Scheme 4. Stille Polymerization toward PTPTPTBT11, PTPTPTBT12, PTPTPTDPP11, PTPTPTDPP12, and PTPTPTDPP13

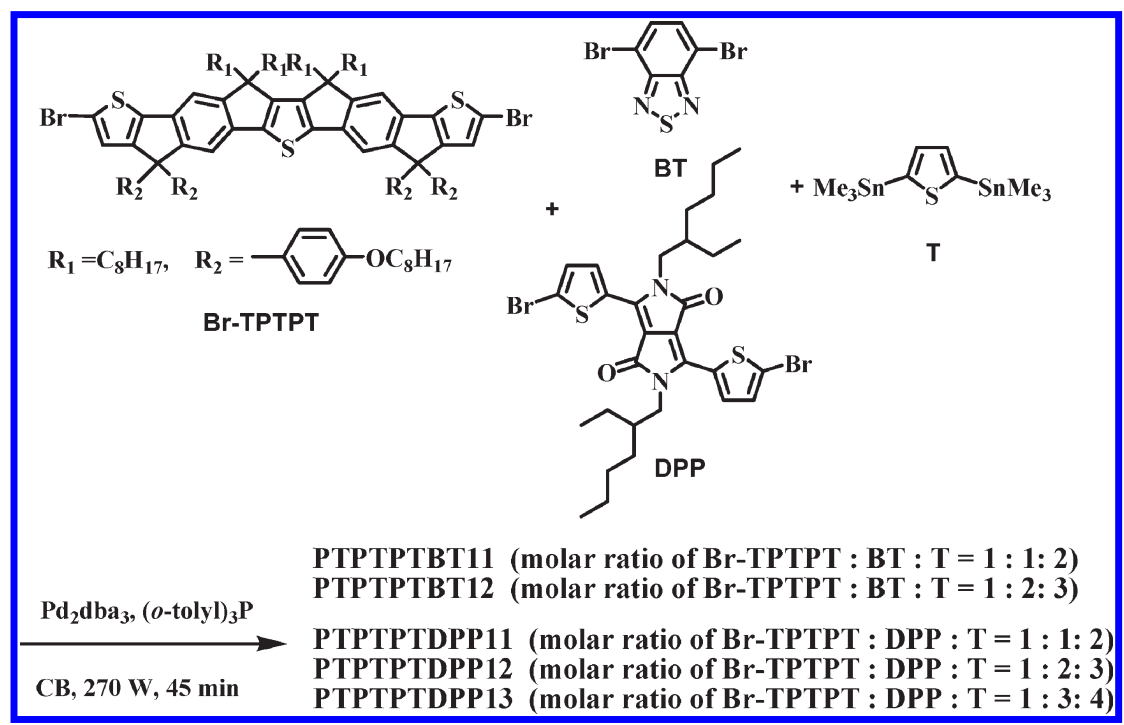

are located at $411-442{ }^{\circ} \mathrm{C}$ (Figure 1), indicating their sufficient thermal stabilities for PSC applications. From the DSC measurement, all of the polymers showed a glass transition temperature around $61-68{ }^{\circ} \mathrm{C}$ without the observation of melting point, suggesting that these random copolymers tend to be amorphous (Figure 2).

Optical Properties. The absorption spectra of all studied polymers were measured in both dilute chloroform (Figure 3 ) and in the thin films (Figure 4), and the correlated optical parameters are summarized in Table 2 .

PTPTPTDPP11, PTPTPTDPP12, and PTPTPTDPP13 copolymers exhibit two distinct bands in the absorption spectra.
One band at shorter wavelengths region $(400-600 \mathrm{~nm})$ is due to localized $\pi-\pi^{*}$ transitions (LT), and the other band at longer wavelengths $(600-900 \mathrm{~nm})$ is attributed to intramolecular charge transfer (ICT) band between electron-rich donors and electron-deficient acceptors. However, the LT and ICT bands of PTPTPTВT11 and РТРТРТВT12 are overlapped into a broad band covering the whole visible region from 400 to $700 \mathrm{~nm}$, indicating that the accepting strength of BT is weaker than that of DPP. Furthermore, as the DPP acceptor content increases from PTPTPTDPP11 to PTPTPTDPP12 and to PTPTPTDPP13, the intensity of the ICT band relative to the LT band also increases significantly. This phenomenon is also observed in the 
Table 1. Molecular Weights, Polydispersity Index, and Thermal Properties of Polymers

\begin{tabular}{lccccc}
\multicolumn{1}{c}{ copolymer } & $M_{\mathrm{w}}{ }^{a}$ & $M_{\mathrm{n}}{ }^{a}$ & $\mathrm{PDI}^{a}$ & $T_{\mathrm{g}}\left({ }^{\circ} \mathrm{C}\right)$ & $T_{\mathrm{d}}\left({ }^{\circ} \mathrm{C}\right)^{b}$ \\
PTPTPTBT11 & 94900 & 38600 & 2.46 & 68 & 435 \\
PTPTPTBT12 & 37800 & 16500 & 2.29 & 64 & 442 \\
PTPTPTDPP11 & 64900 & 30100 & 2.16 & 61 & 441 \\
PTPTPTDPP12 & 28300 & 12900 & 2.19 & 63 & 438 \\
PTPTPTDPP13 & & & & 63 & 411
\end{tabular}

${ }^{a}$ Molecular weights and polydispersity were determined by gel permeation chromatography (GPC) in THF using polystyrene standards. ${ }^{b}$ Decomposition temperature (5\% weight loss) measured by TGA.

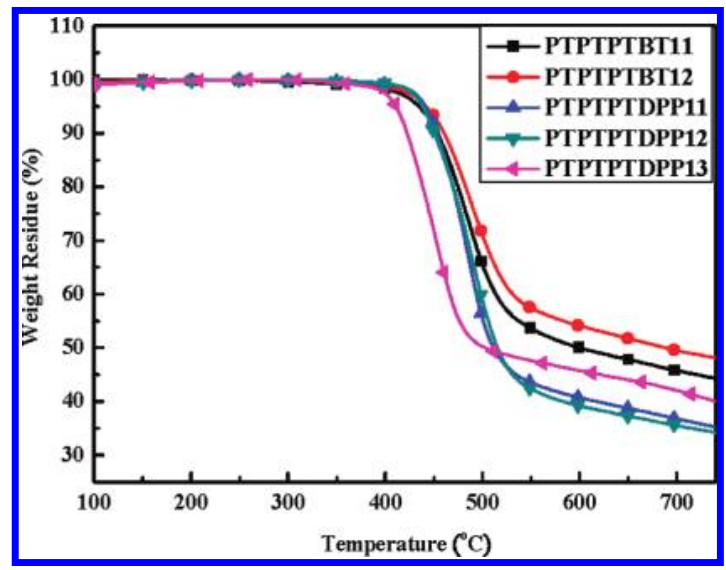

Figure 1. Thermal gravimetric analysis (TGA) measurements of the polymers with a ramping rate of $10^{\circ} \mathrm{C} / \mathrm{min}$.

case of PTPTPTBT11 and PTPTPTBT12. The absorption spectra of all the polymers shifted toward longer wavelengths from the solution state to the solid state, indicating that the planar structure of TPTPT is capable of inducing strong interchain $\pi-\pi$ interactions. The optical band gaps $\left(E_{\mathrm{g}}{ }^{\text {opt }}\right)$ deduced from the absorption edges of thin film spectra are in the following order: PTPTPTDPP13 $(1.37 \mathrm{eV})=$ PTPTPTDPP12 $(1.37 \mathrm{eV})$ < PTPTPTDPP11 (1.39 eV) < PTPTPTBT12 $(1.68 \mathrm{eV})<$ PTРТРТВT11 $(1.73 \mathrm{eV})$.

Electrochemical Properties. Cyclic voltammetry (CV) was employed to examine the electrochemical properties and evaluate the HOMO and LUMO levels of the polymers (Table 3 and Figure 5). All of the polymers showed stable and reversible $\mathrm{p}$-doing and n-doping processes, which are important prerequisites for p-type semiconductor materials. It is found that the HOMO magnitude of the polymers is gradually increased as the acceptor unit content increases. The HOMO energy level is estimated to be -5.16 and $-5.18 \mathrm{eV}$ for PTPTPTBT11 and PТРТРТВT12, respectively, while $-5.16,-5.21$, and $-5.24 \mathrm{eV}$ are for PTPTPTDPP11, PTPTPTDPP12, and PTPTPTDPP13, respectively. According to the HOMO-LUMO energy difference, the band gaps $\left(E_{g}^{\mathrm{el}}\right)$ obtained from CV measurements are greater than the corresponding optical band gaps $\left(E_{\mathrm{g}}{ }^{\mathrm{opt}}\right)$, which is a phenomenon consistent with the reports in the literature. ${ }^{14}$

Hole Mobility and Photovoltaic Characteristics. Bulk heterojunction PSCs were fabricated on the basis of ITO/PEDOT: PSS/polymer: $\mathrm{PC}_{71} \mathrm{BM} / \mathrm{Ca} / \mathrm{Al}$ configuration, and their performances were measured under $100 \mathrm{~mW} / \mathrm{cm}^{2} \mathrm{AM} 1.5$ illumination. Hole-only devices (ITO/PEDOT:PSS/polymer/Au) were

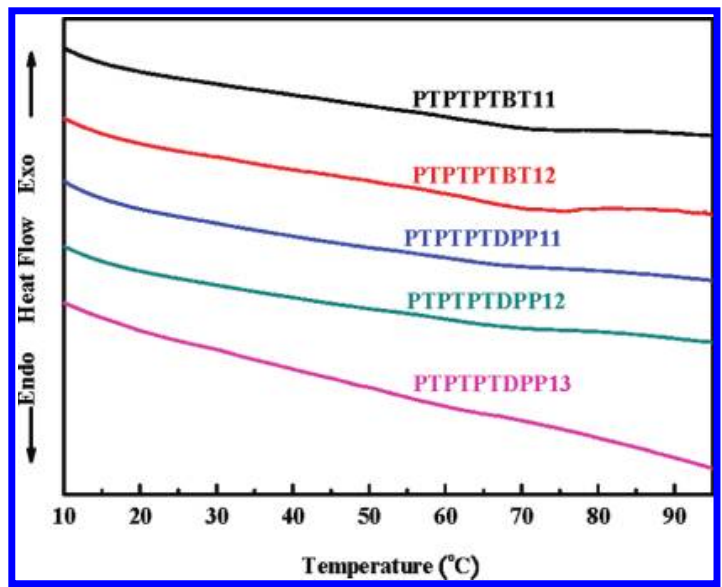

Figure 2. Differential scanning calorimeter (DSC) measurements of the polymers with a ramping rate of $10{ }^{\circ} \mathrm{C} / \mathrm{min}$.

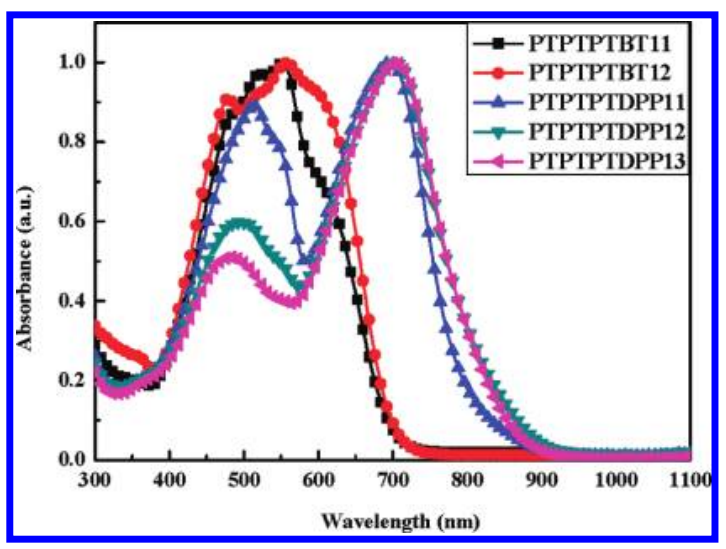

Figure 3. Normalized absorption spectra of the polymers in the chloroform solution.

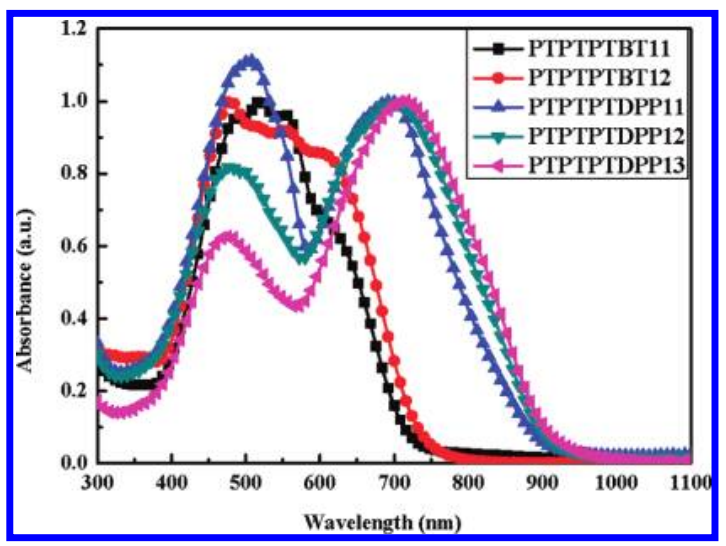

Figure 4. Normalized absorption spectra of the polymers in the thin film.

also fabricated in order to estimate the hole mobilities of these polymers via space-charge limit current (SCLC) theory. The characterization data are summarized in Table 4, and the $J-V$ curves of these polymers are shown in Figure 7. The hole mobility of the polymer follows the trend PTPTPTBT11 $\left(2.9 \times 10^{-6} \mathrm{~cm}^{2} /(\mathrm{V} \mathrm{s})\right)$ $<$ PTPTРТВT12 $\left(3.1 \times 10^{-6} \mathrm{~cm}^{2} /(\mathrm{V} \mathrm{s})\right)<$ PTPTPTDPP11 
Table 2. Optical Properties of the Copolymers in the Chloroform Solution and in the Thin Film

\begin{tabular}{|c|c|c|c|c|c|c|}
\hline \multirow[b]{2}{*}{ polymer } & \multicolumn{3}{|c|}{ chloroform solution } & \multicolumn{3}{|c|}{ thin film } \\
\hline & $\lambda_{\max }(\mathrm{nm})$ & $\lambda_{\text {onset }}(\mathrm{nm})$ & $E_{\mathrm{g}}^{\mathrm{opt}}(\mathrm{eV})$ & $\lambda_{\max }(\mathrm{nm})$ & $\lambda_{\text {onset }}(\mathrm{nm})$ & $E_{\mathrm{g}}^{\mathrm{opt}}(\mathrm{eV})$ \\
\hline РТРТРТВТ11 & 552 & 695 & 1.78 & 553 & 717 & 1.73 \\
\hline РТРТРТВТ12 & 558 & 697 & 1.78 & 553 & 738 & 1.68 \\
\hline PTPTPTDPP11 & 513,696 & 825 & 1.50 & 505,697 & 894 & 1.39 \\
\hline PTPTPTDPP12 & 495,704 & 859 & 1.44 & 494,697 & 903 & 1.37 \\
\hline PTPTPTDPP13 & 482,706 & 862 & 1.44 & 480,712 & 907 & 1.37 \\
\hline
\end{tabular}

Table 3. Electrochemical Onset Potentials and Electronic Energy Levels of the Polymers

\begin{tabular}{|c|c|c|c|c|c|c|}
\hline copolymer & $\begin{array}{c}E_{\mathrm{ox}} \text { onset } \\
(\mathrm{V})\end{array}$ & $\begin{array}{c}E_{\text {red }} \text { onset } \\
\text { (V) }\end{array}$ & $\begin{array}{c}\text { HOMO } \\
(\mathrm{eV})\end{array}$ & $\begin{array}{c}\text { LUMO }^{\text {el }} \\
(\mathrm{eV})\end{array}$ & $\begin{array}{l}\text { LUMO }^{\text {opt }} \\
\qquad(\mathrm{eV})^{a}\end{array}$ & $\begin{array}{l}E_{\mathrm{g}}{ }^{\mathrm{el}} \\
(\mathrm{eV})\end{array}$ \\
\hline РТРТРТВТ11 & 0.36 & 1.46 & -5.16 & -3.34 & -3.43 & 1.82 \\
\hline РТРТРТВТ12 & 0.38 & 1.50 & -5.18 & -3.30 & -3.50 & 1.88 \\
\hline PTPTPTDPP11 & 0.36 & 1.37 & -5.16 & -3.43 & -3.77 & 1.73 \\
\hline РTPTPTDPP12 & 0.41 & 1.39 & -5.21 & -3.41 & -3.84 & 1.80 \\
\hline РТPTPTDPP13 & 0.44 & 1.41 & -5.24 & -3.39 & -3.87 & 1.85 \\
\hline
\end{tabular}

${ }^{a}$ LUMO levels of the polymers were obtained from the equation LUMO $=\mathrm{HOMO}+E_{\mathrm{g}}{ }^{\mathrm{opt}}$.

$\left(1.2 \times 10^{-5} \mathrm{~cm}^{2} /(\mathrm{Vs})\right)<$ PTPTPTDPP13 $\left(2.0 \times 10^{-5} \mathrm{~cm}^{2} /(\mathrm{V} \mathrm{s})\right)$ $<$ PTPTPTDPP12 $\left(2.6 \times 10^{-5} \mathrm{~cm}^{2} /(\mathrm{V} \mathrm{s})\right)$, which indicates that the DPP-based polymers have higher hole mobilities than their corresponding BT-based polymers and the polymers containing higher BT and DPP content exhibit higher hole mobilities. The device based on PTPTPTBT11/PC ${ }_{71} \mathrm{BM}(1: 3, \mathrm{w} / \mathrm{w})$ blend exhibited a $V_{\mathrm{oc}}$ of $0.72 \mathrm{~V}$, a $J_{\mathrm{sc}}$ of $7.8 \mathrm{~mA} / \mathrm{cm}^{2}$, a $\mathrm{FF}$ of $49 \%$, and a PCE of $2.8 \%$, which already outperforms the device based on PDIDTBT11/PC 71 BM $(1: 4, \mathrm{w} / \mathrm{w})$ blend $\left(V_{\mathrm{oc}}=0.68 \mathrm{~V}, J_{\mathrm{sc}}=\right.$ $6.2 \mathrm{~mA} / \mathrm{cm}^{2}$, and a FF $=47 \%$, PCE of $\left.2.0 \%\right) .{ }^{10}$ This result reveals that, compared to the pentacyclic DIDT unit, the nonacyclic TPТPT unit having higher thiophene unit content and more extended planar conjugated system indeed improves all the device characteristics. Furthermore, the device based on РТРТРТВТ12/PC ${ }_{71} \mathrm{BM}(1: 3, \mathrm{w} / \mathrm{w})$ blend delivered a $V_{\mathrm{oc}}$ of $0.74 \mathrm{~V}$, a $J_{\mathrm{sc}}$ of $8.34 \mathrm{~mA} / \mathrm{cm}^{2}$, and a $\mathrm{FF}$ of $50 \%$, producing an improved PCE of $3.1 \%$. This enhancement may be ascribed to the PTPTPTBT12's better absorption ability and slightly higher hole mobility over PTPTPTBT11. The same trend was also observed in the DPP-based copolymers. The PTPTPTDPP11/ $\mathrm{PC}_{71} \mathrm{BM}(1: 4, \mathrm{w} / \mathrm{w})$-based device showed a high $J_{\mathrm{sc}}$ of $9.64 \mathrm{~mA} /$ $\mathrm{cm}^{2}$ and a FF of $54 \%$, leading to a PCE to $3.6 \%$, while the PTPTPTDPP12/PC ${ }_{71} \mathrm{BM}(1: 4, \mathrm{w} / \mathrm{w})$-based device exhibited the best performance with a highest $J_{\mathrm{sc}}$ of $10.78 \mathrm{~mA} / \mathrm{cm}^{2}$ and a higher PCE of $4.3 \%$. The much boarder absorption window and much higher hole mobility of DPP-based polymers might be responsible for the better photocurrent and efficiency of the devices compared to their corresponding BT-based polymers. However, further increasing the DPP content in PTPTPTDPP13 relative to PTPTPTDPP12 turns out to slightly decrease its hole mobility $\left(2.0 \times 10^{-5} \mathrm{~cm}^{2} /(\mathrm{V} \mathrm{s})\right)$. Consistently, the device using blend indeed showed a slight decreased PCE value of $4.1 \%$.

Devices with inverted architecture are known to possess much improved long-term stability compared to conventional structure. However, PCEs of P3HT/PCBM-based inverted PSCs are mostly in the range of ca. $2-4 \%$, which is inferior to that of

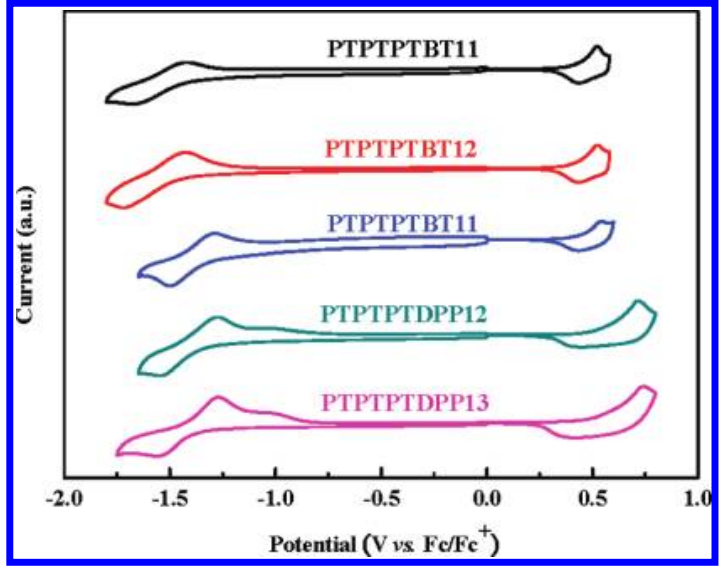

Figure 5. Cyclic voltammograms of the polymers in the thin film at a scan rate of $80 \mathrm{mV} / \mathrm{s}$.

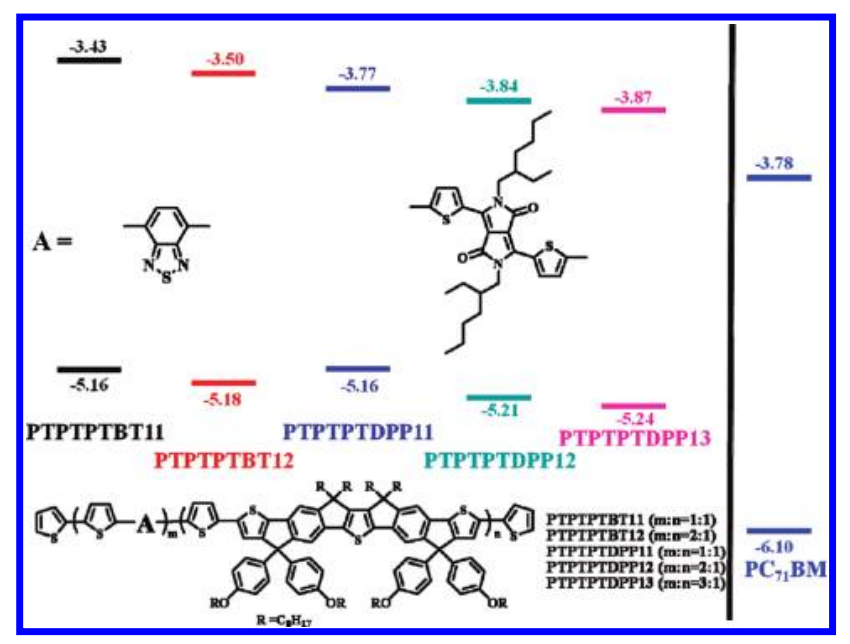

Figure 6. Energy diagram of HOMO-LUMO levels for the polymers and $\mathrm{PC}_{71} \mathrm{BM}$.

conventional PSCs. ${ }^{15}$ Therefore, recent research efforts on device engineering and interfacial modification of inverted solar cells are mostly focused on $\mathrm{P} 3 \mathrm{HT} / \mathrm{PC}_{61} \mathrm{BM}$ material system. The utilization of LBG conjugated polymers other than P3HT as p-type photoactive materials is only sporadically explored. ${ }^{16}$ Recently, we have demonstrated that integration of a crosslinked fullerene interlayer (C-PCBSD) with zinc oxide significantly enhances the inverted device characteristics. ${ }^{17}$ It is highly desirable to evaluate PTPTPTDPP-based copolymers in the application of inverted devices. Accordingly, on the basis of 
Table 4. Photovoltaic Characteristics

\begin{tabular}{|c|c|c|c|c|c|c|}
\hline copolymer & $\begin{array}{c}\text { wt } \% \text { ratio of } \\
\text { copolymer and } \mathrm{PC}_{71} \mathrm{BM}\end{array}$ & $\begin{array}{c}\text { mobility } \\
\left(\mathrm{cm}^{2} /(\mathrm{Vs})\right)\end{array}$ & $\begin{array}{l}V_{\mathrm{oc}} \\
(\mathrm{V})\end{array}$ & $\begin{array}{c}J_{\mathrm{sc}} \\
\left(\mathrm{mA} / \mathrm{cm}^{2}\right)\end{array}$ & $\begin{array}{l}\mathrm{FF} \\
(\%)\end{array}$ & $\begin{array}{l}\text { PCE } \\
(\%)\end{array}$ \\
\hline РТРТРТВТ11 $^{a}$ & $1: 3$ & $2.9 \times 10^{-6}$ & 0.72 & 7.80 & 49 & 2.8 \\
\hline${\text { РТРТРТВТ } 12^{a}}^{a}$ & $1: 3$ & $3.1 \times 10^{-6}$ & 0.74 & 8.34 & 50 & 3.1 \\
\hline PTPTPTDPP11 ${ }^{a}$ & $1: 4$ & $1.2 \times 10^{-5}$ & 0.70 & 9.64 & 54 & 3.6 \\
\hline PTPTPTDPP $12^{a}$ & $1: 4$ & $2.6 \times 10^{-5}$ & 0.68 & $10.78(10.08)^{c}$ & 58 & 4.3 \\
\hline${\text { PTPTPTDPP } 13^{a}}^{a}$ & $1: 3$ & $2.0 \times 10^{-5}$ & 0.68 & $9.27(9.09)^{c}$ & 65 & 4.1 \\
\hline PTPTPTDPP $12^{b}$ & $1: 4$ & & 0.70 & $11.71(11.36)^{c}$ & 62 & 5.1 \\
\hline${\text { PTPTPTDPP } 13^{b}}^{b}$ & $1: 3$ & & 0.68 & $10.97(10.81)^{c}$ & 61 & 4.6 \\
\hline
\end{tabular}

${ }^{a}$ Conventional device structure: ITO/PEDOT:PSS/copolymer:PC ${ }_{71} \mathrm{BM} / \mathrm{Ca} / \mathrm{Al} .{ }^{b}$ Inverted device structure: ITO/ZnO/C-PCBSD/copolymer: $\mathrm{PC}_{71} \mathrm{BM} / \mathrm{PEDOT}: \mathrm{PSS} / \mathrm{Ag} .{ }^{c}$ Calculated from the EQE spectrum.

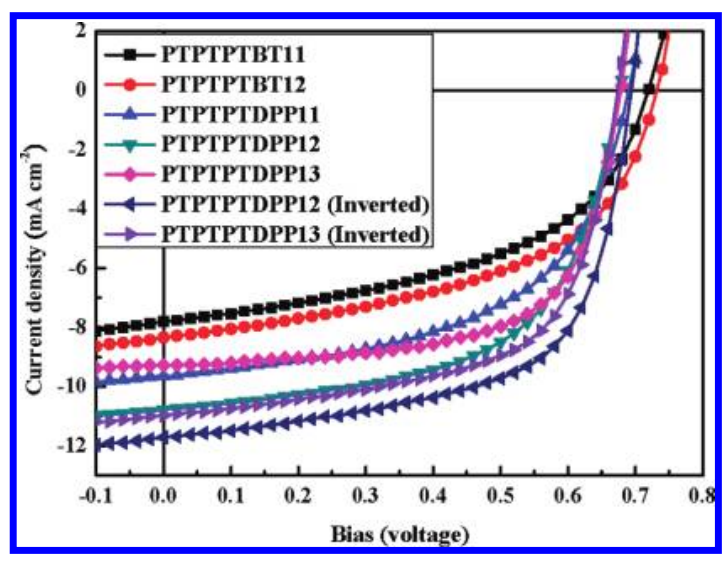

Figure 7. $J-V$ characteristics of ITO/PEDOT:PSS/polymer:PC ${ }_{71} \mathrm{BM} /$ $\mathrm{Ca} / \mathrm{Al}$ under illumination of AM1.5, $100 \mathrm{~mW} / \mathrm{cm}^{2}$.

ITO/ZnO/C-PCBSD/copolymer:PC ${ }_{71}$ BM/PEDOT:PSS/Ag configuration, the inverted device based on the PTPTPTDPP13/PC 71 BM (1:3, w/w) blend was fabricated, delivering a high PCE of $4.6 \%$. More encouragingly, the device incorporating PTPTPTDPP12/ $\mathrm{PC}_{71} \mathrm{BM}(1: 4, \mathrm{w} / \mathrm{w})$ blend further achieved an impressive PCE of $5.1 \%$ with $J_{\mathrm{sc}}=11.71 \mathrm{~mA} / \mathrm{cm}^{2}, V_{\mathrm{oc}}=0.70 \mathrm{~V}$, and $\mathrm{FF}=62 \%$. This performance not only outperforms the $\mathrm{P} 3 \mathrm{HT} / \mathrm{PC}_{61} \mathrm{BM}$-based device under identical device configuration ${ }^{17}$ but also is already comparable to an inverted tandem cell $(\mathrm{PCE}=5.1 \%)$ combining P3HT and poly[bis(2-ethylhexyl)dithienosilole)-alt-(2,1,3-benzothiadiazole)] (PSBTBT) as the photoactive materials. ${ }^{18}$ To confirm the accuracy of the measurements of the devices, the corresponding external quantum efficiency (EQE) spectra for both the conventional and inverted solar cells using PTPTPTDPP12 and PTPTPTDPP13 were measured under illumination of monochromatic light (Figure 8). The $J_{\text {sc }}$ values calculated from integration of the EQE spectra are shown in Table 4 and agree well with the $J_{\text {sc }}$ obtained from the $J-V$ measurements.

Notably, these values are superior to those obtained from the corresponding conventional devices. The improved efficiency is mainly due to the enhanced $J_{\mathrm{sc}}\left(9.27\right.$ vs $10.97 \mathrm{~mA} / \mathrm{cm}^{2}$ for PTPTPTDPP13 system and 10.78 vs $11.71 \mathrm{~mA} / \mathrm{cm}^{2}$ for PTPTPTDPP12 system). In a conventional device, PEDOT:PSS is the first layer that encounters the irradiation light. Because of the fact that PEDOT:PSS has strong absorption in the near-infrared (NIR) region $(600-1000 \mathrm{~nm})$, the solar light in the this region will be inevitably absorbed by the PEDOT:PSS layer, which in turn decreases the solar absorption of copolymers in the active layer. This optical loss is more pronounced when a LBG polymer having a broad absorption extending to NIR region is employed. Nevertheless, in an inverted device, the PEDOT:PSS layer is placed behind the active layer without affecting the coming light. The enhanced absorption ability of the active layer is thus associated with the improved photocurrent in the inverted device. This result demonstrates that PTPTPTDPP-based LBG polymers are specifically superior photoactive materials for inverted solar cell applications.

\section{CONCLUSIONS}

We have successfully designed and synthesized a novel laddertype interfused TPTPT unit where each thiophene ring is covalently fastened with the adjacent benzene ring by a carbon bridge, embedding four cyclopentadiene rings in the nonacyclic structure. The coplanar TPTPT building block and electrondeficient acceptors 2,7-dibromobenzothiadiazole (BT) or 2,7dibromodithienyldiketopyrrolopyrrole (DPP) were copolymerized with 2,5-bis(trimethylstannyl)thiophene by Stille polymerization. The molar feed ratio of TPTPT to BT or DPP can be adjusted to modulate the optical and electronic properties, leading to five random copolymers, PTPTPTBT11, PTPTPTBT12, PTPTPTDPP11, PTPTPTDPP12, and PTPTPTDPP13. The device based on the PTPTPTBT11/PC ${ }_{71} \mathrm{BM}$ blend exhibited a PCE of $2.8 \%$, which already outperforms the device based on the PDIDTBT11/ $\mathrm{PC}_{71} \mathrm{BM}$ blend with a PCE of $2.0 \%$, revealing that, compared to pentacyclic DIDT unit, nonacyclic TPTPT unit indeed improves all the device characteristics due to its higher thiophene unit content and more extended planar conjugated system. The optimized performance of the devices incorporating these polymers follows the trend PTPTPTDPP12 $>$ PTPTPTDPP13 > PTPTPTDPP11 > PTPTPTBT12 > РТРТРТВT11, which is in good agreement with the trend of their optical band gaps and hole mobilities. Because of the much boarder absorption ability and the highest hole mobility of PTPTPTDPP12, the device based on PTPTPTDPP12/ $\mathrm{PC}_{71} \mathrm{BM}(1: 4, \mathrm{w} / \mathrm{w})$ exhibited the highest $J_{\mathrm{sc}}$ of $10.78 \mathrm{~mA} / \mathrm{cm}^{2}$ and an impressive PCE of $4.3 \%$. Moreover, the inverted device with the configuration of ITO/ZnO/C-PCBSD/PTPTPTDPP12/PC ${ }_{71} \mathrm{BM}(1: 4, \mathrm{w} / \mathrm{w}) /$ PEDOT:PSS/Ag exhibited a high PCE of $5.1 \%$, which is among the highest efficiency for inverted solar cells incorporating a low-band-gap polymer.

\section{EXPERIMENTAL SECTION}

General Measurement and Characterization. All chemicals are purchased from Aldrich or Acros and used as received unless 


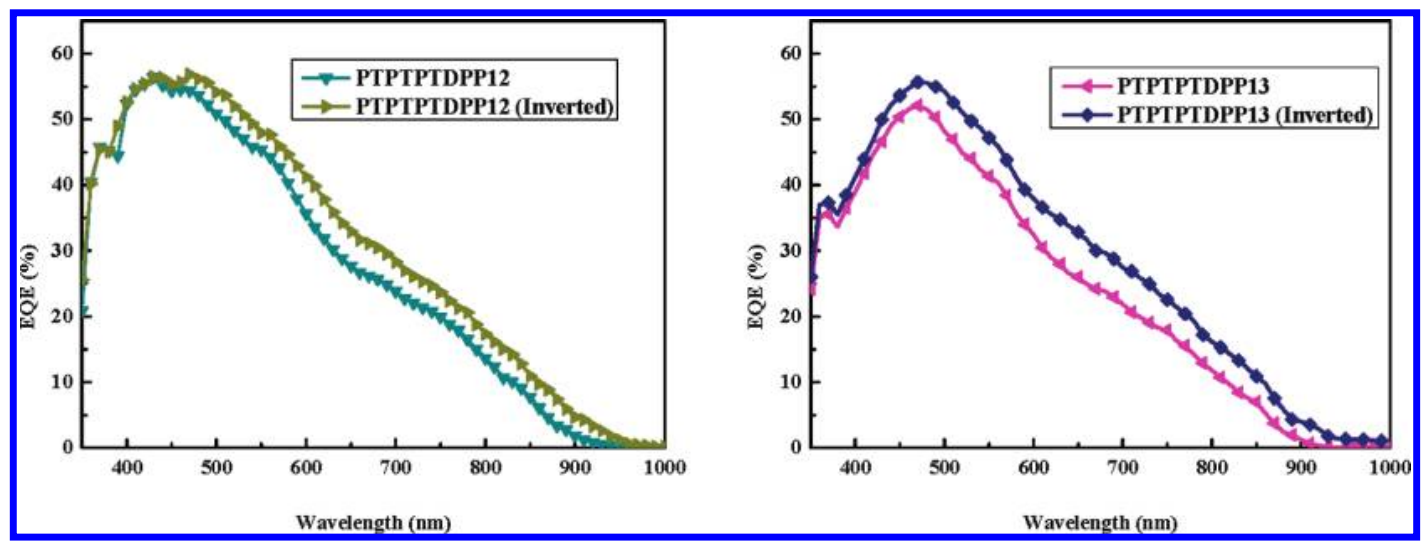

Figure 8. EQE spectra of the conventional and inverted devices for PTPTPTDPP12 (left) and PTPTPTDPP13 (right).

otherwise specified. ${ }^{1} \mathrm{H}$ and ${ }^{13} \mathrm{C}$ NMR spectra were measured using Varian $300 \mathrm{MHz}$ instrument spectrometer. The molecular weight of polymers was measured by the GPC method (Viscotek VE2001GPC), and polystyrene was used as the standard (THF as the eluent). Differential scanning calorimetry (DSC) was measured on TA Q200 Instrument, and thermal gravimetric analysis (TGA) was recorded on Perkin-Elmer Pyris under a nitrogen atmosphere at a heating rate of $10{ }^{\circ} \mathrm{C} / \mathrm{min}$. Absorption spectra were taken on a HP8453 UV-vis spectrophotometer. The electrochemical cyclic voltammetry was conducted on a Bioanalytical Systems Inc. analyzer. A carbon glass coated with a thin polymer film was used as the working electrode and an $\mathrm{Ag} /$ $\mathrm{AgCl}$ as the reference electrode, while $0.1 \mathrm{M}$ tetrabutylammonium hexafluorophosphate $\left(\mathrm{TBAPF}_{6}\right)$ in acetonitrile was the electrolyte. $\mathrm{CV}$ curves were calibrated using ferrocence as the standard, whose HOMO is set at $-4.8 \mathrm{eV}$ with respect to zero vacuum level. The HOMO energy levels were obtained from the equation $\mathrm{HOMO}=-\left(E_{\text {ox }}{ }^{\text {onset }}-\right.$ $E_{\text {(ferrocene) }}$ onset +4.8$) \mathrm{eV}$. The LUMO levels of polymer were obtained from the equation LUMO $\left.=-\left(E_{\text {red }}{ }^{\text {onset }}-E_{\text {(ferrocene })}\right)^{\text {onset }}+4.8\right) \mathrm{eV}$.

Fabrication and Characterization of BHJ Devices. ITO/glass substrates were ultrasonically cleaned sequentially in detergent, water, acetone, and isopropyl alcohol. Then, the substrates were covered by a $30 \mathrm{~nm}$ thick layer of PEDOT:PSS (Clevios P provided by H. C. Stark) by spin-coating. After annealing in air at $150{ }^{\circ} \mathrm{C}$ for $30 \mathrm{~min}$, the samples were cooled down to rt. Polymers were dissolved in $o$-dichlorobenzene (ODCB) (0.47 wt \%), and $\mathrm{PC}_{71} \mathrm{BM}$ (purchased from Nano-C) was added to reach the desired ratio. The solution was then heated at $110^{\circ} \mathrm{C}$ and stirred overnight. Prior to deposition, the solution was filtrated through a $0.45 \mu \mathrm{m}$ filter and the substrates were transferred in a glovebox. The photoactive layer was then spin-coated at different spin-coating speed in order to tune its thickness. After drying, the samples were annealed for $15 \mathrm{~min}$. The detailed processing parameters (spin-coating speed; annealing temperature) are shown as follows: РТРТРТВT $11 / \mathrm{PC}_{71} \mathrm{BM}\left(800 \mathrm{rpm} ; 150^{\circ} \mathrm{C}\right)$, РTPTPTBT $12 / \mathrm{PC}_{71} \mathrm{BM}$ $\left(800 \mathrm{rpm}, 150{ }^{\circ} \mathrm{C}\right)$, РTPTPTDPP11/PC ${ }_{71} \mathrm{BM}$ (1000 rpm; without annealing), PTPTPTDPP12/PC 71 BM (1000 rpm; without annealing), PTPTPTDPP13/PC ${ }_{71} \mathrm{BM}$ (1000 rpm; without annealing). The cathode made of calcium ( $35 \mathrm{~nm}$ thick) and aluminum (100 nm thick) was evaporated through a shadow mask under high vacuum $\left(<10^{-6}\right.$ Torr $)$. Each device is constituted of 4 pixels defined by an active area of $0.04 \mathrm{~cm}^{2}$. Finally, the devices were encapsulated, and $I-V$ curves were measured in air.

For the inverted architecture, a $\mathrm{ZnO}$ precursor solution, consisting of $157 \mathrm{mg} \mathrm{mL}^{-1}$ zinc acetate dehydrate in $96 \% 2$-methoxyethanol and $4 \%$ ethanolamine, was spin-coated onto ITO-coated glass, followed by thermal annealing in air at $300{ }^{\circ} \mathrm{C}$ for $10 \mathrm{~min}$ to crystallize the film (thickness $=50 \mathrm{~nm})$. Subsequently, $\mathrm{PCBSD}$ solution $\left(5 \mathrm{mg} \mathrm{mL}^{-1}\right.$ in $o$ dichlorobenzene) was spin-coated onto the $\mathrm{ZnO}$ layer, and the as-cast film was heated at $180^{\circ} \mathrm{C}$ for $10 \mathrm{~min}$ for thermal cross-linking (thickness $=10 \mathrm{~nm}$ ). The same process for the active layer in the conventional architecture was used for the inverted devices. The PEDOT:PSS solution diluted with equal volumes of isopropyl alcohol and $0.2 \mathrm{wt} \%$ of Triton X-100 nonionic surfactant was then spin-coated on top of the active layer, followed by thermal annealing at $120{ }^{\circ} \mathrm{C}$ for $10 \mathrm{~min}$ (thickness $=60 \mathrm{~nm})$. A silver top electrode (thickness $=150 \mathrm{~nm})$ was then thermally evaporated to complete the inverted device.

Electrical Characterization under Illumination. The devices were characterized under $100 \mathrm{~mW} / \mathrm{cm}^{2}$ AM 1.5 simulated light measurement (Yamashita Denso solar simulator). Current-voltage $(J-V)$ characteristics of PSC devices were obtained by a Keithley 2400 SMU. Solar illumination conforming the JIS Class AAA was provided by a SAN-EI 300W solar simulator equipped with an AM 1.5G filter. The light intensity was calibrated with a Hamamatsu S1336-5BK silicon photodiode. The performances presented here are the average of the 4 pixels of each device.

Hole-Only Devices. In order to investigate the respective hole mobility of the different copolymer films, unipolar devices have been prepared following the same procedure except that the active layer is made of pure polymer and the $\mathrm{Ca} / \mathrm{Al}$ cathode is replaced by evaporated gold $(40 \mathrm{~nm})$. The hole mobilities were calculated according to space charge limited current theory (SCLC). The $J-V$ curves were fitted according to the following equation:

$$
J=\frac{9}{8} \varepsilon \mu \frac{V^{2}}{L^{3}}
$$

where $\varepsilon$ is the dielectric permittivity of the polymer, $\mu$ is the hole mobility, and $L$ is the film thickness (distance between the two electrodes).

Synthesis of Compound 6. To a $50 \mathrm{~mL}$ round-bottom flask was introduced 5 ( $2.20 \mathrm{~g}, 2.29 \mathrm{mmol})$, ethyl 2-bromothiophene-3-carboxylate $(1.24 \mathrm{~g}, 5.27 \mathrm{mmol}), \mathrm{Pd}\left(\mathrm{PPh}_{3}\right)_{4}(0.265 \mathrm{~g}, 0.23 \mathrm{mmol}), \mathrm{K}_{2} \mathrm{CO}_{3}$ $(1.90 \mathrm{~g}, 13.75 \mathrm{mmol})$, Aliquant $336(0.23 \mathrm{~g}, 0.57 \mathrm{mmol})$, degas toluene $(17 \mathrm{~mL})$, and degas $\mathrm{H}_{2} \mathrm{O}(3.5 \mathrm{~mL})$. The mixture was heated to $90{ }^{\circ} \mathrm{C}$ under nitrogen gas for $72 \mathrm{~h}$. The reaction solution was extracted with ethyl acetate $(300 \mathrm{~mL} \times 3)$ and water $(150 \mathrm{~mL})$. The combined organic layer was dried over $\mathrm{MgSO}_{4}$. After removal of the solvent under reduced pressure, the residue was purified by column chromatography on silica gel (hexane/ethyl acetate, v/v, 20/1) and then recrystallized from hexane to give a light yellow solid $6(2.07 \mathrm{~g}, 62 \%)$; mp: $110{ }^{\circ} \mathrm{C} .{ }^{1} \mathrm{H}$ NMR $\left(\mathrm{CDCl}_{3}, 300 \mathrm{MHz}\right): 7.52(\mathrm{~d}, J=5.6 \mathrm{~Hz}, 2 \mathrm{H}), 7.51-7.30(\mathrm{~m}, 6$ $\mathrm{H}), 3.17-3.58(\mathrm{~m}, 4 \mathrm{H}), 7.23(\mathrm{~d}, J=5.6 \mathrm{~Hz}, 2 \mathrm{H}), 4.20(\mathrm{q}, J=7.2 \mathrm{~Hz}, 4$ $\mathrm{H}), 2.09(\mathrm{t}, J=8.1 \mathrm{~Hz}, 8 \mathrm{H}), 1.40-0.96(\mathrm{~m}, 54 \mathrm{H}), 0.82(\mathrm{t}, J=13.4 \mathrm{~Hz}$, $12 \mathrm{H}) .{ }^{13} \mathrm{C} \mathrm{NMR}\left(\mathrm{CDCl}_{3}, 75 \mathrm{MHz}\right): 163.4,152.0,151.6,149.9,144.8$, 139.3, 130.0, 128.8, 128.1, 123.6, 123.5, 117.3, 60.4, 55.6 40.2, 31.8, 30.3, 
29.6, 29.5, 24.2, 22.6, 14.2, 14.0. MS (FAB, $\left.\mathrm{C}_{64} \mathrm{H}_{88} \mathrm{O}_{4} \mathrm{~S}_{3}\right)$ : calcd, 1017.58; found, 1017.

Synthesis of Compound 7. A Grignard reagent was prepared by the following procedure. To a suspension of magnesium turnings $(0.8 \mathrm{~g}$, $33.3 \mathrm{mmol})$ and 3-4 drops of 1,2-dibromoethane in dry THF $(20 \mathrm{~mL})$ was slowly added 1-bromo-4-(octyloxy)benzene ( $8.56 \mathrm{~g}, 30.0 \mathrm{mmol}$ ) dropwise and stirred for $1 \mathrm{~h}$. To a solution of $6(0.80 \mathrm{~g}, 0.79 \mathrm{mmol})$ in dry THF $(20 \mathrm{~mL})$ under nitrogen was added 4-(octyloxy)benzene 1-magnesium bromide $(20 \mathrm{~mL}, 7.9 \mathrm{mmol})$ dropwise at room temperature. The resulting mixture was heated at reflux for $16 \mathrm{~h}$. The reaction solution was extracted with ethyl acetate $(150 \mathrm{~mL} \times 3)$ and water $(100 \mathrm{~mL})$. The combined organic layer was dried over $\mathrm{MgSO}_{4}$. After removal of the solvent under reduced pressure, the residue was purified by column chromatography on silica gel (hexane/ethyl acetate, $\mathrm{v} / \mathrm{v}, 100 / 1$ ) to give a yellow oil $7(1.17 \mathrm{~g}, 85 \%) .{ }^{1} \mathrm{H}$ NMR $\left(\mathrm{CDCl}_{3}, 300 \mathrm{MHz}\right): 7.24$ (d, $J=9.0 \mathrm{~Hz}, 2 \mathrm{H}), 7.17(\mathrm{~d}, J=9.0 \mathrm{~Hz}, 2 \mathrm{H}), 7.16(\mathrm{~d}, J=9.0 \mathrm{~Hz}, 8 \mathrm{H}), 7.09$ $(\mathrm{d}, J=5.1 \mathrm{~Hz}, 2 \mathrm{H}), 6.94(\mathrm{~s}, 2 \mathrm{H}), 6.84(\mathrm{~d}, J=9.0 \mathrm{~Hz}, 8 \mathrm{H}), 6.41(\mathrm{~d}, J=5.6$ $\mathrm{Hz}, 2 \mathrm{H}), 3.97(\mathrm{t}, J=6.5 \mathrm{~Hz}, 8 \mathrm{H}), 3.07(\mathrm{~s}, 2 \mathrm{H}), 1.95-1.60(\mathrm{~m}, 16 \mathrm{H})$, $1.55-0.40(\mathrm{~m}, 112 \mathrm{H}) .{ }^{13} \mathrm{C}$ NMR $\left(\mathrm{CDCl}_{3}, 75 \mathrm{MHz}\right): 158.2,152.5$, 149.7, 144.5, 144.1, 140.7, 139.2, 138.8, 131.5, 131.0, 128.9, 123.1, 122.2, $117.9,113.7,80.4,68.0,55.4,39.9,31.9,31.8,30.2,29.7,29.5,29.4,29.3$, 29.26, 26.1, 24.1, 22.7, 22.6, 14.1, 14.05. MS (FAB, $\left.\mathrm{C}_{116} \mathrm{H}_{164} \mathrm{O}_{6} \mathrm{~S}_{3}\right)$ : calcd, 1750.73; found, 1751.

Synthesis of Compound TPTPT. To a solution of 7 ( $2.00 \mathrm{~g}, 1.14$ $\mathrm{mmol})$ in boiling acetic acid $(116 \mathrm{~mL})$ was added concentrated sulfuric acid $(3.5 \mathrm{~mL})$ in one portion. The resulting solution was stirred for $18 \mathrm{~h}$ at $95{ }^{\circ} \mathrm{C}$ and then was extracted with ethyl acetate $(500 \mathrm{~mL} \times 3)$ and water $(250 \mathrm{~mL})$. The combined organic layer was dried over $\mathrm{MgSO}_{4}$. After removal of the solvent under reduced pressure, the residue was purified by column chromatography on silica gel (hexane/ethyl acetate, $\mathrm{v} / \mathrm{v}, 100 / 1)$ to give an orange oil TPTPT (1.58 g, 81\%). ${ }^{1} \mathrm{H}$ NMR (d-THF, $300 \mathrm{MHz}): 7.45(\mathrm{~s}, 2 \mathrm{H}), 7.34(\mathrm{~d}, J=4.8 \mathrm{~Hz}, 2 \mathrm{H}), 7.33(\mathrm{~s}, 2 \mathrm{H})$, $7.12(\mathrm{~d}, J=8.7 \mathrm{~Hz}, 8 \mathrm{H}), 6.99(\mathrm{~d}, J=4.8 \mathrm{~Hz}, 2 \mathrm{H}), 6.72(\mathrm{~d}, J=8.7 \mathrm{~Hz}, 8$ $\mathrm{H}), 3.87(\mathrm{t}, J=6.0 \mathrm{~Hz}, 8 \mathrm{H}), 2.3-2.1(\mathrm{~m}, 8 \mathrm{H}), 1.50-0.95(\mathrm{~m}, 96 \mathrm{H})$, $0.90-0.70(\mathrm{~m}, 24 \mathrm{H}) .{ }^{13} \mathrm{C} \mathrm{NMR}\left(\mathrm{CDCl}_{3}, 75 \mathrm{MHz}\right): 157.9,155.9,153.2$, 152.2, 148.9, 144.6, 141.3, 137.1, 137.0, 134.3, 129.0, 126.9, 123.0, 115.8, $114.1,113.1,67.9,61.8,55.1,40.5,31.9,31.85,31.8,30.3,29.7,29.5$, 29.3, 29.29, 29.2, 26.0, 24.2, 22.6, 14.1, 14.0. MS (FAB, $\left.\mathrm{C}_{116} \mathrm{H}_{160} \mathrm{O}_{4} \mathrm{~S}_{3}\right)$ : calcd, 1714.70; found, 1715 .

Synthesis of Monomer Br-TPTPT. To a solution of TPTPT $(1.58 \mathrm{~g}, 0.92 \mathrm{mmol})$ in chloroform $(87 \mathrm{~mL})$ was added $N$-bromosuccinimide $(0.36 \mathrm{~g}, 2.23 \mathrm{mmol})$ in one portion at room temperature. The flask was wrapped with alumiunm foil and stirred for $12 \mathrm{~h}$ at room temperature and then was quenched by water $(100 \mathrm{~mL})$. The mixture solution was extracted with chloroform $(450 \mathrm{~mL} \times 3)$ and water $(150 \mathrm{~mL})$. The combined organic layer was dried over $\mathrm{MgSO}_{4}$. After removal of the solvent under reduced pressure, the residue was purified by column chromatography on silica gel (hexane/ethyl acetate, v/v, $100 / 1)$ and then recrystallized from hexane to give an orange solid Br-TPTPT (1.12 g, 65\%); mp: $127^{\circ} \mathrm{C} .{ }^{1} \mathrm{H} \mathrm{NMR}\left(\mathrm{CDCl}_{3}, 300 \mathrm{MHz}\right): 7.23$ $(\mathrm{s}, 2 \mathrm{H}), 7.18(\mathrm{~s}, 2 \mathrm{H}), 7.12(\mathrm{~d}, J=8.7 \mathrm{~Hz}, 8 \mathrm{H}), 6.99(\mathrm{~s}, 2 \mathrm{H}), 6.78(\mathrm{~d}, J=$ $8.7 \mathrm{~Hz}, 8 \mathrm{H}), 3.90(\mathrm{t}, J=6.5 \mathrm{~Hz}, 8 \mathrm{H}), 2.07(\mathrm{t}, J=8.0 \mathrm{~Hz}, 8 \mathrm{H}), 1.80-1.70$ $(\mathrm{m}, 8 \mathrm{H}), 1.50-0.60(\mathrm{~m}, 112 \mathrm{H}) .{ }^{13} \mathrm{C} \mathrm{NMR}\left(\mathrm{CDCl}_{3}, 75 \mathrm{MHz}\right): 158.1$, 154.6, 152.4, 152.2, 149.1, 144.7, 141.6, 137.3, 136.3, 133.9, 128.9, 126.0, 124.0, 115.7, 114.2, 113.0, 67.9, 62.6, 55.2, 40.4, 31.9, 31.8, 31.4, 30.3, 30.2, 29.7, 29.6, 29.5, 29.3, 29.27, 29.2, 26.0, 24.2, 22.6, 14.1, 14.0. MS (FAB, $\mathrm{C}_{116} \mathrm{H}_{158} \mathrm{Br}_{2} \mathrm{O}_{4} \mathrm{~S}_{3}$ ): calcd, 1872.5; found, 1872. Elemental analysis (\%) Calcd for $\mathrm{C}_{116} \mathrm{H}_{158} \mathrm{Br}_{2} \mathrm{O}_{4} \mathrm{~S}_{3}$ : C, 74.41; $\mathrm{H}, 8.50$. Found: C, 74.35; H, 8.43.

Synthesis of PTPTPTBT11. To a $100 \mathrm{~mL}$ round-bottom flask was introduced Br-TPTPT (228.5 mg, $0.12 \mathrm{mmol}$ ), 4,7-dibromo-2,1,3-benzothiadiazole BT $(35.9 \mathrm{mg}, 0.12 \mathrm{mmol}), 2,5$-bis(trimethylstannyl)thiophene (100 mg, $0.24 \mathrm{mmol}), \mathrm{Pd}_{2}(\mathrm{dba})_{3}(8.9 \mathrm{mg}, 0.0098 \mathrm{mmol})$, tri(o-tolyl)phosphine $(23.8 \mathrm{mg}, 0.078 \mathrm{mmol})$, and dry chlorobenzene $(5 \mathrm{~mL})$. The mixture was then degassed by bubbling nitrogen for $10 \mathrm{~min}$ at room temperature. The round-bottom flask was placed into the microwave reactor and reacted for $45 \mathrm{~min}$ under $270 \mathrm{~W}$. Then, tributyl(thiophen2-yl)stannane (22.8 mg, $0.061 \mathrm{mmol})$ was added to the mixture solution and reacted for $10 \mathrm{~min}$ under $270 \mathrm{~W}$. Finally, 2-bromothiophene $(9.9 \mathrm{mg}$, $0.061 \mathrm{mmol}$ ) was added to the mixture solution and reacted for $10 \mathrm{~min}$ under $270 \mathrm{~W}$. The solution was added into methanol dropwise. The precipitate was collected by filtration and washed by Soxhlet extraction with acetone, hexane, and chloroform sequentially for 1 week. The Pdthiol gel (Silicycle Inc.) and Pd-TAAcOH were added to above chloroform solution to remove the residual Pd catalyst and Sn metal. After filtration and removal of the solvent, the polymer was redissolved in chloroform again and added into methanol to reprecipitate out. The purified polymer was collected by filtration and dried under vacuum for 1 day to give a dark-green strip $\left(228 \mathrm{mg}, 87 \%, M_{\mathrm{n}}=39000, \mathrm{PDI}=2.46\right)$. ${ }^{1} \mathrm{H}$ NMR $\left(\mathrm{CDCl}_{3}, 300 \mathrm{MHz}\right): 8.30-7.80(\mathrm{~m}, 8 \mathrm{H}), 7.25-7.15(\mathrm{~m}$, $10 \mathrm{H}), 7.20-7.10(\mathrm{~m}, 2 \mathrm{H}), 6.95-6.75(\mathrm{~m}, 8 \mathrm{H}), 4.05-3.80(\mathrm{~m}, 8 \mathrm{H})$, $2.30-2.00(\mathrm{~m}, 8 \mathrm{H}), 1.85-1.65(\mathrm{~m}, 8 \mathrm{H}), 1.50-0.60(\mathrm{~m}, 112 \mathrm{H})$.

Synthesis of PTPTPTBT12. To a $100 \mathrm{~mL}$ round-bottom flask was introduced Br-TPTPT (155 mg, 0.08 mmol), 4,7-dibromo-2,1,3-benzothiadiazole BT (47.3 mg, $0.16 \mathrm{mmol}$ ), 2,5-bis(trimethylstannyl)thiophene (100 $\mathrm{mg}, 0.24 \mathrm{mmol}), \mathrm{Pd}_{2}(\mathrm{dba})_{3}(8.9 \mathrm{mg}, 0.0098 \mathrm{mmol})$, tri(o-tolyl)phosphine $(23.8 \mathrm{mg}, 0.078 \mathrm{mmol})$, and dry chlorobenzene $(5 \mathrm{~mL})$. The mixture was then degassed by bubbling nitrogen for $10 \mathrm{~min}$ at room temperature. The round-bottom flask was placed into the microwave reactor and reacted for $45 \mathrm{~min}$ under $270 \mathrm{~W}$. Then, tributyl(thiophen-2-yl)stannane $(22.8 \mathrm{mg}$, $0.061 \mathrm{mmol}$ ) was added to the mixture solution and reacted for $10 \mathrm{~min}$ under $270 \mathrm{~W}$. Finally, 2-bromothiophene $(9.9 \mathrm{mg}, 0.061 \mathrm{mmol}$ ) was added to the mixture solution and reacted for 10 min under $270 \mathrm{~W}$. The solution was added into methanol dropwise. The precipitate was collected by filtration and washed by Soxhlet extraction with acetone, hexane, and chloroform sequentially for 1 week. The Pd-thiol gel (Silicycle Inc.) and Pd$\mathrm{TAAcOH}$ were added to above chloroform solution to remove the residual Pd catalyst and Sn metal. After filtration and removal of the solvent, the polymer was redissolved in chloroform again and added into methanol to reprecipitate out. The purified polymer was collected by filtration and dried under vacuum for 1 day to give a black solid ( $95.8 \mathrm{mg}, 33 \%, M_{\mathrm{n}}=17000$, PDI = 2.29). ${ }^{1} \mathrm{H} \mathrm{NMR}\left(\mathrm{CDCl}_{3}, 300 \mathrm{MHz}\right): 8.30-7.80(\mathrm{~m}, 12 \mathrm{H}), 7.25-$ $7.15(\mathrm{~m}, 10 \mathrm{H}), 7.20-7.10(\mathrm{~m}, 2 \mathrm{H}), 6.95-6.75(\mathrm{~m}, 8 \mathrm{H}), 4.05-3.80$ $(\mathrm{m}, 8 \mathrm{H}), 2.30-2.00(\mathrm{~m}, 8 \mathrm{H}), 1.85-1.65(\mathrm{~m}, 8 \mathrm{H}), 1.50-0.50(\mathrm{~m}, 112 \mathrm{H})$.

Synthesis of PTPTPTDPP11. To a $100 \mathrm{~mL}$ round-bottom flask was introduced Br-TPTPT (228.5 mg, $0.12 \mathrm{mmol}$ ), 2,7-dibromodithienyldiketopyrrolopyrrole DPP ( $83.3 \mathrm{mg}, 0.12 \mathrm{mmol}), 2,5$-bis(trimethylstannyl)thiophene $(100 \mathrm{mg}, 0.24 \mathrm{mmol}), \mathrm{Pd}_{2}(\mathrm{dba})_{3}(8.9 \mathrm{mg}, 0.0098$ $\mathrm{mmol})$, tri (o-tolyl)phosphine $(23.8 \mathrm{mg}, 0.078 \mathrm{mmol})$, and dry chlorobenzene $(5 \mathrm{~mL})$. The mixture was then degassed by bubbling nitrogen for $10 \mathrm{~min}$ at room temperature. The round-bottom flask was placed into the microwave reactor and reacted for $45 \mathrm{~min}$ under $270 \mathrm{~W}$. Then, tributyl(thiophen-2-yl)stannane $(22.8 \mathrm{mg}, 0.061 \mathrm{mmol})$ was added to the mixture solution and reacted for $10 \mathrm{~min}$ under $270 \mathrm{~W}$. Finally, 2-bromothiophene $(9.9 \mathrm{mg}, 0.061 \mathrm{mmol})$ was added to the mixture solution and reacted for $10 \mathrm{~min}$ under $270 \mathrm{~W}$. The solution was added into methanol dropwise. The precipitate was collected by filtration and washed by Soxhlet extraction with acetone, hexane, and chloroform sequentially for 1 week. The Pd-thiol gel (Silicycle Inc.) and Pd-TAAcOH were added to above chloroform solution to remove the residual Pd catalyst and Sn metal. After filtration and removal of the solvent, the polymer was redissolved in chloroform again and added into methanol to reprecipitate out. The purified polymer was collected by filtration and dried under vacuum for 1 day to give a green strip $\left(262 \mathrm{mg}, 85 \%, M_{\mathrm{n}}=30000, \mathrm{PDI}=2.16\right) .{ }^{1} \mathrm{H} \mathrm{NMR}\left(\mathrm{CDCl}_{3}\right.$, $300 \mathrm{MHz}): 9.05-8.90(\mathrm{~m}, 2 \mathrm{H}), 7.25-7.00(\mathrm{~m}, 18 \mathrm{H}), 6.95-6.75(\mathrm{~m}, 10 \mathrm{H})$, $4.05-3.80(\mathrm{~m}, 12 \mathrm{H}), 2.20-1.90(\mathrm{~m}, 2 \mathrm{H}), 1.80-1.65(\mathrm{~m}, 8 \mathrm{H})$, $1.50-0.60(\mathrm{~m}, 148 \mathrm{H})$.

Synthesis of PTPTPTDPP12. To a $100 \mathrm{~mL}$ round-bottom flask was introduced Br-TPTPT (155 mg, $0.08 \mathrm{mmol}$ ), 2,7-dibromodithienyl- 
diketopyrrolopyrrole DPP (109.9 mg, $0.16 \mathrm{mmol}$ ), 2,5-bis(trimethylstannyl)thiophene (100 mg, $0.24 \mathrm{mmol}), \mathrm{Pd}_{2}(\mathrm{dba})_{3}(8.9 \mathrm{mg}, 0.0098$ $\mathrm{mmol})$, tri (o-tolyl)phosphine $(23.8 \mathrm{mg}, 0.078 \mathrm{mmol})$, and dry chlorobenzene $(5 \mathrm{~mL})$. The mixture was then degassed by bubbling nitrogen for $10 \mathrm{~min}$ at room temperature. The round-bottom flask was placed into the microwave reactor and reacted for $45 \mathrm{~min}$ under $270 \mathrm{~W}$. Then, tributyl(thiophen-2-yl)stannane $(22.8 \mathrm{mg}, 0.061 \mathrm{mmol})$ was added to the mixture solution and reacted for $10 \mathrm{~min}$ under $270 \mathrm{~W}$. Finally, 2-bromothiophene $(9.9 \mathrm{mg}, 0.061 \mathrm{mmol})$ was added to the mixture solution and reacted for 10 min under $270 \mathrm{~W}$. The solution was added into methanol dropwise. The precipitate was collected by filtration and washed by Soxhlet extraction with acetone, hexane, and chloroform sequentially for 1 week. The Pd-thiol gel (Silicycle Inc.) and Pd-TAAcOH were added to above chloroform solution to remove the residual $\mathrm{Pd}$ catalyst and Sn metal. After filtration and removal of the solvent, the polymer was redissolved in chloroform again and added into methanol to reprecipitate out. The purified polymer was collected by filtration and dried under vacuum for 1 day to give a dark-green strip (130 mg, $35 \%$, $\left.M_{\mathrm{n}}=13000, \mathrm{PDI}=2.19\right) .{ }^{1} \mathrm{H} \mathrm{NMR}\left(\mathrm{CDCl}_{3}, 300 \mathrm{MHz}\right): 9.05-8.90(\mathrm{~m}$, $4 \mathrm{H}), 7.25-7.00(\mathrm{~m}, 20 \mathrm{H}), 6.95-6.75(\mathrm{~m}, 12 \mathrm{H}), 4.05-3.80(\mathrm{~m}, 16 \mathrm{H})$, $2.20-1.90(\mathrm{~m}, 4 \mathrm{H}), 1.80-1.65(\mathrm{~m}, 8 \mathrm{H}), 1.50-0.60(\mathrm{~m}, 176 \mathrm{H})$.

Synthesis of PTPTPTDPP13. To a $100 \mathrm{~mL}$ round-bottom flask was introduced Br-TPTPT (114.2 mg, $0.06 \mathrm{mmol}$ ), 3,6-bis(5-bromothiophen-2-yl)-2,5-bis(2-ethylhexyl)pyrrolo[3,4-c]pyrrole-1,4(2H,5H)-dione A2 (124.9 mg, $0.18 \mathrm{mmol}), 2,5$-bis(trimethylstannyl)thiophene (100 mg, $0.24 \mathrm{mmol}), \mathrm{Pd}_{2}(\mathrm{dba})_{3}(8.9 \mathrm{mg}, 0.0098 \mathrm{mmol})$, tri(o-tolyl)phosphine $(23.8 \mathrm{mg}, 0.078 \mathrm{mmol})$, and dry chlorobenzene $(5 \mathrm{~mL})$. The mixture was then degassed by bubbling nitrogen for $10 \mathrm{~min}$ at room temperature. The round-bottom flask was placed into the microwave reactor and reacted for $45 \mathrm{~min}$ under $270 \mathrm{~W}$. Then, tributyl(thiophen-2-yl)stannane $(22.8 \mathrm{mg}$, $0.061 \mathrm{mmol}$ ) was added to the mixture solution and reacted for $10 \mathrm{~min}$ under $270 \mathrm{~W}$. Finally, 2-bromothiophene $(9.9 \mathrm{mg}, 0.061 \mathrm{mmol})$ was added to the mixture solution and reacted for $10 \mathrm{~min}$ under $270 \mathrm{~W}$. The solution was added into methanol dropwise. The precipitate was collected by filtration and washed by Soxhlet extraction with acetone, hexane, and chloroform sequentially for 1 week. The Pd-thiol gel (Silicycle Inc.) and Pd-TAAcOH were added to above chloroform solution to remove the residual Pd catalyst and Sn metal. After filtration and removal of the solvent, the polymer was redissolved in chloroform again and added into methanol to reprecipitate out. The purified polymer was collected by filtration and dried under vacuum for 1 day to give a black solid $(60 \mathrm{mg}, 16 \%) .{ }^{1} \mathrm{H} \mathrm{NMR}\left(\mathrm{CDCl}_{3}\right.$, $300 \mathrm{MHz}): 9.05-8.90(\mathrm{~m}, 6 \mathrm{H}), 7.25-7.00(\mathrm{~m}, 22 \mathrm{H}), 6.95-6.75$ $(\mathrm{m}, 14 \mathrm{H}), 4.05-3.80(\mathrm{~m}, 20 \mathrm{H}), 2.20-1.90(\mathrm{~m}, 6 \mathrm{H}), 1.80-1.65$ $(\mathrm{m}, 8 \mathrm{H}), 1.50-0.60(\mathrm{~m}, 204 \mathrm{H})$.

\section{ASSOCIATED CONTENT}

Supporting Information. ${ }^{1} \mathrm{H}$ and ${ }^{13} \mathrm{C}$ NMR spectra of all intermediates, monomers, and corresponding copolymers. This material is available free of charge via the Internet at http://pubs. acs.org.

\section{AUTHOR INFORMATION}

\section{Corresponding Author}

*E-mail: yjcheng@mail.nctu.edu.tw (Y.-J.C.); cshsu@mail.nctu. edu.tw (C.-S.H.).

\section{ACKNOWLEDGMENT}

We thank the National Science Council and the "ATU Program" of the Ministry of Education, Taiwan, for financial support.

\section{REFERENCES}

(1) (a) Yu, G.; Gao, J.; Hummelen, J. C.; Wudl, F.; Heeger, A. J. Science 1995, 270, 1789. (b) Günes, S.; Neugebauer, H.; Sariciftci, N. S. Chem. Rev. 2007, 107, 1324. (c) Thompson, B. C.; Fréchet, J. M. J. Angew. Chem. Int. Ed. 2008, 47, 58. (d) Cheng, Y.-J.; Yang, S.-H.; Hsu, C.-S. Chem. Rev. 2009, 109, 5868.

(2) (a) Roncali, J. Chem. Rev. 1997, 97, 173. (b) van Mullekom, H. A. M.; Vekemans, J. A. J. M.; Havinga, E. E.; Meijer, E. W. Mater. Sci. Eng. R 2001, 32, 1. (c) Chen, J.; Cao, Y. Acc. Chem. Res. 2009, 42, 1709.

(3) (a) Zheng, Q.; Jung, B. J.; Sun, J.; Katz, H. E. J. Am. Chem. Soc. 2010, 132, 5394. (b) Wu, J.-S.; Cheng, Y.-J.; Dubosc, M.; Hsieh, C.-H.; Chang, C.-Y.; Hsu, C.-S. Chem. Commun. 2010, 46, 3259. (c) Liang, Y.; Xu, Z.; Xia, J.; Tsai, S.-T.; Wu, Y.; Li, G.; Ray, C.; Yu, L. Adv. Mater. 2010, 22, 1. (d) Huo, L.; Hou, J.; Zhang, S.; Chen, H.-Y.; Yang, Y. Angew. Chem. Int. Ed. 2010, 49, 1500. (e) Allard, N.; Ä̈ch, R. B.; Gendron, D.; Boudreault, P.-L. T.; Tessier, C.; Alem, S.; Tse, S.-C.; Tao, Y.; Leclerc, M. Macromolecules 2010, 43, 2328. (f) Blouin, N.; Michaud, A.; Leclerc, M. Adv. Mater. 2007, 19, 2295. (g) Zhou, E.; Nakamura, M.; Nishizawa, T.; Zhang, Y.; Wei, Q.; Tajima, K.; Yang, C.; Hashimoto, K. Macromolecules 2008, 41, 8302. (h) Hou, J.; Chen, H.-Y.; Zhang, S.; Li, G.; Yang, Y. I.Am. Chem. Soc. 2008, 130, 16144. (i) Cheng, Y.-J.; Wu., J.-S.; Shih, P.-I.; Chang, C.-Y.; Jwo, P.-C.; Kuo, W.-S.; Hsu, C.-S. Chem. Mater. 2011, 23, 2361.

(4) (a) Roncali, J. Macromol. Rapid Commun. 2007, 28, 1761 and references therein. (b) Forster, M.; Annan, K. O.; Scherf, U. Macromolecules 1999, 32, 3159.

(5) (a) Brédas, J. L.; Calbert, J. P.; da Silva Filho, D. A.; Cornil, J. Proc. Natl. Acad. Sci. U. S. A. 2002, 99, 5804. (b) Ando, S.; Nishida, J.-I.; Tada, H.; Inoue, Y.; Tokito, S.; Yamashita, Y. J. Am. Chem. Soc. 2005, 127, 5336. (c) Baek, N.-S.; Hau, S. K.; Yip, H.-L.; Acton, O.; Chen, K.-S.; Jen, A. K.-Y. Chem. Mater. 2008, 20, 5734. (d) Liang, Y.; Wu, Y.; Feng, D.; Tsai, S.-T.; Son, H.-J.; Li, G.; Yu, L. I. Am. Chem. Soc. 2009, 131, 56.

(6) (a) Svensson, M.; Zhang, F.; Veenstra, S. C.; Verhees, W. J. H.; Hummelen, J. C.; Kroon, J. M.; Inganäs, O.; Andersson, M. R. Adv. Mater. 2003, 15, 988. (b) Zhou, Q.; Hou, Q.; Zheng, L.; Deng, X.; Yu, G.; Cao, Y. Appl. Phvs. Lett. 2004, 84, 1653. (c) Zhang, F.; Perzon, E.; Wang, X.; Mammo, W.; Andersson, M. R.; Inganäs, O. Adv. Funct. Mater. 2005, 15, 745. (d) Zhang, F.; Mammo, W.; Andersson, L. M.; Admassie, S.; Andersson, M. R.; Inganäs, O. Adv. Mater. 2006, 18, 2169. (e) Slooff, L. H.; Veenstra, S. C.; Kroon, J. M.; Moet, D. J. D.; Sweelssen, J.; Koetse, M. M. Appl. Phvs. Lett. 2007, 90, 143506. (f) Zhang, F.; Bijleveld, J.; Perzon, E.; Tvingstedt, K.; Barrau, S.; Inganäs, O.; Andersson, M. R. I. Mater. Chem. 2008, 18, 5468. (g) Schulz, G. L.; Chen, X.; Holdcroft, S. Appl. Phys. Lett. 2009, 94, 023302. (h) Huang, F.; Chen, K.-S.; Yip, H.-L.; Hau, S. K.; Acton, O.; Zhang, Y.; Luo, J.; Jen, A. K.-Y. J. Am. Chem. Soc. 2009, 131, 13886-13887.

(7) Coppo, P.; Turner, M. L. L. Mater. Chem. 2005, 15, 1123 and references therein.

(8) (a) Zhu, Z.; Waller, D.; Gaudiana, R.; Morana, M.; Mühlbacher, D.; Scharber, M.; Brabec, C. Macromolecules 2007, 40, 1981. (b) Mühlbacher, D.; Scharber, M.; Zhengguo, M. M.; Zhu, M. M. Z.; Waller, D.; Gaudiana, R.; Brabec, C. Adv. Mater. 2006, 18, 2884. (c) Kim, J. Y.; Lee, K.; Coates, N. E.; Moses, D.; Nguyen, T.-Q.; Dante, M.; Heeger, A. J. Science 2007, 317, 222. (d) Peet, J.; Kim, J. Y.; Coates, N. E.; Ma, W. L.; Moses, D.; Heeger, A. J.; Bazan, G. C. Nature Mater. 2007, 6, 497. (e) Chen, C.-H.; Hsieh, C.-H.; Dubosc, M.; Cheng, Y.-J.; Hsu, C.-S. Macromolecules 2010, 43, 697.

(9) (a) Baierweck, P.; Simmross, U.; Müllen, K. Chem. Ber. 1988, 121, 2195. (b) Roncali, J.; Thobie-Gautier, C. Adv. Mater. 1994, 6, 846. (c) Kowada, T.; Kuwabara, T.; Ohe, K. I. Org. Chem. 2010, 75, 906. (d) Afonina, I.; Coles, S. J.; Hursthouse, M. B.; Kanibolotsky, A.; Skabara, P. J. Acta Crystallogr., Sect. E: Struct. Rep. Online 2008, 64, 0167.

(10) Chen, C.-H.; Cheng, Y.-J.; Dubosc, M.; Hsieh, C.-H.; Chu, C.-C.; Hsu, C.-S. Chem.-Asian.I. 2010, 5, 2483.

(11) (a) Slooff, L. H.; Veenstra, S. C.; Kroon, J. M.; Moet, D. J. D.; Sweelssen, J.; Koetse, M. M. Appl. Phvs. Lett. 2007, 90, 143506. (b) Huo, L.; Hou, J.; Zhang, S.; Chen, H.-Y.; Yang, Y. Angew. Chem., Int. Ed. 2010, 
49, 1500. (c) Blouin, N.; Michaud, A.; Gendron, D.; Wakim, S.; Blair, E.; Neagu-Plesu, R.; Belletête, M.; Durocher, G.; Tao, Y.; Leclerc, M. J. Am. Chem. Soc. 2008, 130, 732. (d) Chan, S.-H.; Hsiao, Y.-S.; Hung, L.-I.; Hwang, G.-W.; Chen, H.-L.; Ting, C.; Chen, C.-P. Macromolecules 2010, 43, 3399. (e) Park, S. H.; Roy, A.; Beaupré, S.; Cho, S.; Coates, N.; Moon, J. S.; Moses, D.; Leclerc, M.; Lee, K.; Heeger, A. J. Nature Photonics 2009, 3, 297. (f) Kim, J. Y.; Lee, K.; Coates, N. E.; Moses, D.; Nguyen, T.-Q.; Dante, M.; Heeger, A. I. Science 2007, 317, 222.

(12) (a) Yu, C.-Y.; Chen, C.-P.; Chan, S.-H.; Hwang, G.-W.; Ting, C. Chem. Mater. 2009, 21, 3262. (b) Bijleveld, J. C.; Zoombelt, A. P.; Mathijssen, S. G. J.; Wienk, M. M.; Turbiez, M.; de Leeuw, D. M.; Janssen, R. A. J. I.Am. Chem. Soc. 2009, 131, 16616. (c) Huo, L.; Hou, J.; Chen, H.-Y.; Zhang, S.; Jiang, Y.; Chen, T. L.; Yang, Y. Macromolecules 2009, 42, 6564.

(13) (a) Zhou, Q.; Hou, Q.; Zheng, L.; Deng, X.; Yu, G.; Cao, Y. Appl.Phvs. Lett. 2004, 84, 1653. (b) Hou, Q.; Xu, Y.; Yang, W.; Yuan, M.; Peng, J.; Cao, Y. L. Mater. Chem. 2002, 12, 2887. (c) Schulz, G. L.; Holdcroft, S. Chem. Mater. 2008, 20, 5351. (d) Hou, J.; Tan, Z.; Yan, Y.; He, Y.; Yang, C.; Li, Y. I.Am. Chem. Soc. 2006, 128, 4911. (e) Li, Y.; Zou, Y. Adv. Mater. 2008, 20, 2952. (f) Zhou, E.; Tan, Z.; Yang, Y.; Huo, L.; Zou, Y.; Yang, C.; Li, Y. Macromolecules 2007, 40, 1831. (g) Liang, Y.; Xiao, S.; Feng, D.; Yu, L. I. Phvs. Chem. C 2008, 112, 7866. (h) Hou, J.; Tan, Z.; He, Y.; Yang, C.; Li, Y. Macromolecules 2006, 39, 4657. (i) Peng, Q.; Park, K.; Lin, T.; Durstock, M.; Dai, L. J. Phys. Chem. B 2008, 112, 2801.

(14) (a) Wienk, M. M.; Kroon, J. M.; Verhees, W. J. H.; Knol, J.; Hummelen, J. C.; van Hal, P. A.; Janssen, R. A. J. Angew. Chem., Int. Ed. 2003, 42, 3371. (b) Yao, Y.; Shi, C.; Li, G.; Shrotriya, V.; Pei, Z.; Yang, Y. Appl. Phvs. Lett. 2006, 89, 153507.

(15) (a) Liao, H.-H.; Chen, L.-M.; Xu, Z.; Li, G.; Yang, Y. Appl. Phys. Lett. 2008, 92, 173303. (b) Mor, G. K.; Shankar, K.; Paulose, M.; Varghese, O. K.; Grimes, C. A. Appl. Phvs. Lett. 2007, 91, 152111. (c) Waldauf, C.; Morana, M.; Denk, P.; Schilinsky, P.; Coakley, K.; Choulis, S. A.; Brabec, C. I. Appl. Phvs. Lett. 2006, 89, 233517. (d) White, M. S.; Olson, D. C.; Shaheen, S. E.; Kopidakis, N.; Ginley, D. S. Appl. Phys. Lett. 2006, 89, 143517. (e) Steim, R.; Choulis, S. A.; Schilinsky, P.; Brabec, C. I. Appl. Phvs. Lett. 2008, 92, 093303. (f) Wang, T.; Cai, W.; Qin, D.; Wang, E.; Lan, L.; Gong, X.; Peng, J.; Cao, Y. J. Phys. Chem. C 2010, 114, 6849. (g) Hau, S. K.; Yip, H.-L.; Baek, N. S.; Zou, J.; O'Malley, K.; Jen, A. K.-Y. Appl. Phvs. Lett. 2008, 92, 253301. (h) Hau, S. K.; Yip, H.-L.; Acton, O.; Baek, N. S.; Ma, H.; Jen, A. K.-Y. J. Mater. Chem. 2008, 18, 5113. (i) Hau, S. K.; Yip, H.-L.; Ma, H.; Jen, A. K.-Y. Appl. Phvs. Lett. 2008, 93, 233304. (j) Chen, F.-.C.; Wu, J.-L.; Hung, Y. Appl. Phvs. Lett. 2010, 96, 193304.

(16) (a) Yang, T.; Cai, W.; Qin, D.; Wang, E.; Lan, L.; Gong, X.; Peng, J.; Cao., Y. I. Phvs. Chem. C 2010, 114, 6849. (b) Zhang, Y.; Hau, S. K.; Yip, H.-L.; Sun, Y.; Acton, O.; Jen, A. K.-Y. Chem. Mater. 2010, 22, 2696.

(17) (a) Hsieh, C.-H.; Cheng, Y.-J.; Li, P.-J.; Chen, C.-H.; Dubosc, M.; Liang, R.-M.; Hsu, C.-S. I. Am. Chem. Soc. 2010, 132, 4887.

(b) Cheng, Y.-J.; Hsieh, C.-H.; He, Y.; Hsu, C.-S.; Li, Y. J. Am. Chem. Soc. 2010, 132, 17381.

(18) Chou, C.-H.; Kwan, W. L.; Hong, Z.; Chen, L.-M.; Yang, Y. Adv. Mater. 2011, 23, 1282. 